\title{
A University Training Programme for Acquiring Entrepreneurial and Transversal Employability Skills, a Students' Assessment
}

\author{
Pilar Laguna-Sánchez *, Pilar Abad, Concepción de la Fuente-Cabrero $\mathbb{D}$ and Rocío Calero \\ Business Department, University Rey Juan Carlos, 28032 Madrid, Spain; pilar.abad@urjc.es (P.A.); \\ concepcion.delafuente@urjc.es (C.d.l.F.-C.); rocio.calero@urjc.es (R.C.) \\ * Correspondence: pilar.laguna@urjc.es
}

Received: 20 December 2019; Accepted: 18 January 2020; Published: 21 January 2020

check for updates

\begin{abstract}
The objective of this paper is to analyze university graduate students' assessments of the attainment of skills acquired in a Training Programme (TP) to develop entrepreneurial skills and transversal employability competencies. Both are vital for the success of today's societies and play an important role in the sustainable development agenda. The TP was a 12-week programme with six modules combining entrepreneurship training and traditional teaching methods. There were nine editions and 148 students worked in teams preparing business plans to present to consultants and potential investors. First, the nominal group technique was used to identify which competencies can be acquired through TP. Second, a survey was designed to identify the level to which the competences were attained. The results suggest that the students attained two types of skills, acquiring a higher level of proficiency in entrepreneurial skills and those transversal competencies. Additionally, different levels of attainment of entrepreneurial skills were found in different groups of students. We provide new evidence that TPs, as compulsory subjects in the core curriculum of degree programmes, will help accomplish both objectives: the acquisition of entrepreneurial skills and generic university educational competencies. The overall outcome of this research highlights the value added by the TPs.
\end{abstract}

Keywords: sustainable development agenda; higher education; employability competencies; entrepreneurial skills training

\section{Introduction}

The development of entrepreneurship educational and the employability skills is a relevant factor in achieving the Sustainable Development Goal 4 (SDG4) of the 2030 Agenda of the United Nations (UN) General Assembly. SDG4 aims to "ensure inclusive and equitable quality education and promote lifelong learning opportunities for all" and defines SDG4's Target 4.4 as "[to] substantially increase the number of youth and adults who have relevant skills for employment, decent jobs and entrepreneurship" [1,2]. In ESDG 4, UNESCO recommends that education for sustainable development should be included in all formal education curricula: primary, secondary, and higher education and that the learner should be able to "recognize the importance of their own skills for improving their life, in particular for employment and entrepreneurship" [3].

Entrepreneurship is considered a key element for innovation and economic and social development [4-6]. The current consensus considers entrepreneurship to be a discipline with certain skills and abilities that can be learned [7-9] and the EU has stated that the greatest impact on entrepreneurship education is achieved in higher levels of education [10].

In relation to employability competencies, international organizations consider the hard ones, technical and analytical, that allow the worker to perform the mechanical aspects of the job; and the 
soft ones, or transversal skills, that are defined as intangible personal qualities required to be effective in the work place, these skills cut across jobs and sectors [11-14]. The World Economic Forum (WEF) points out that those skills such as creativity, originality, initiative, critical thinking, flexibility, complex problem-solving, emotional intelligence, and leadership will likewise retain or increase their value in an international labor market [15]. The European Union (EU), since the implementation of the Bologna Process and the publishing of the Tuning Project outcomes, has fostered changes in the approach to learning in universities in order to improve the acquisition of generic and transversal competencies. Likewise, the EU recommends enhancing creativity and innovation, including entrepreneurship at all levels of education and training [16-18].

Initiative and entrepreneurial spirit identified in the Tunning Report [16] is considered a transversal systemic skill that improves employability in the labor market; it is appreciated in paid employment as it is entrepreneurial [19-22].

Therefore, the development of education for sustainability requires encouraging entrepreneurial skills and transversal competencies in Higher Education Institutions (HEIs). Universities and business schools currently offer Entrepreneurship Programmes based on teaching methods that identify opportunities, estimate the resources required, and indicate how to acquire them and start up a new business $[23,24]$. The literature evaluates efficiency in terms of entrepreneurial intention, entrepreneurial activity, the acquired skills, etc. [8,25-31]. Recent research at a university in Spain [19] analyzes the effects of training entrepreneurial competences on employability, considering entrepreneurship to be a transversal competence aimed at increasing employability. Following the literature, our paper tests the effectiveness of a Training Program (TP) in terms of two kinds of acquired competences: employment or entrepreneurial and transversal generic competences. To our knowledge, there is no a study that tests the effectiveness of a TP considering both kinds of competencies simultaneously.

The TP designed by University Rey Juan Carlos in collaboration with Obra Social La Caixa (the Foundation of Caixa Bank, the third Spanish bank in the activity ranking) combines training in entrepreneurship and traditional teaching methods for degree students in order to develop entrepreneurial skills and employability transversal competencies jointly. The purpose of this paper is to evaluate the effectiveness of the TP in terms of entrepreneurial skills acquired by students jointly with certain generic competencies, taking into account the assessment made by the university students who carried out the TP.

The paper begins with a review of the important role of HEIs in the promotion of entrepreneurial skills and transversal employability competencies, identifying those most required by university graduates in the labor market and by institutions, as well the methodologies used for their development and the evaluation of their effectiveness, always from the perspective of the connection between entrepreneurial and employability competencies. Secondly, in the Section 3, the TP is outlined and the research design is shown, including the methods used to select the competences, the questionnaire, and the sample. Then, the most important study results are presented. Finally, the discussion, main conclusions, and limitations are provided in the last section.

The main results show that the students attained two types of skills, acquiring a higher level of proficiency in entrepreneurial and employability transversal competencies. Consequently, this research makes a relevant contribution to the literature. As the programme increases the university generic transversal competencies simultaneously with entrepreneurial ones, universities will have more incentive to include TP to develop entrepreneurial skills and transversal employability competencies in their degree curricula. As the authors of [32] show: "Further research on how universities influence their students in the cultivation of entrepreneurial competencies and how entrepreneurial competencies of students can be improved by programmes that are designed and developed by policy makers, university academics and managers of all university-level centers". 


\section{Literature Review}

Despite the importance of promoting the acquisition of entrepreneurial skills in education [7-10], the teaching of entrepreneurship is not yet sufficiently integrated into higher education institutions' curricula and the NIRAS survey showed that half the European students in advanced education did not have access to an education in entrepreneurship as curricular or non-curricular activities $[33,34]$. Therefore, universities can play an important role both in the curricula offered [35], as well as their entrepreneurship education programmes [25].

Many methods are used to provide training in entrepreneurship: identification of opportunities in new trades or start-ups, elaboration of business plans, interviews with entrepreneurs, information on entrepreneurship as a professional career option, case studies to identify opportunities in new business and activities designed to develop entrepreneurial skills, etc. [23,24,36,37]. However, a consensus does not exist on how to provide education on entrepreneurship, for example using training methods versus traditional teaching methods. In [26] the authors found that the relationship between entrepreneurship outcomes and entrepreneurship education is more academically-focused than training-focused; on the other hand, the authors of $[33,38]$ suggest that traditional teaching methods tend to be ineffective in entrepreneurship learning. The lack of consensus on how to teach entrepreneurship is quite likely related to the low awareness until now of the objectives of entrepreneurship training [39].

The methodologies used to measure the efficiency of entrepreneurial education programmes are mainly focused on three areas: entrepreneurial intention, entrepreneurial activity, and acquired skills. However, there is evidence of the positive effects on a broad range of inputs. The EU revised 51 examples of measuring the impact of entrepreneurship training (classes, courses, programmes, and modules) on the objectives of the activity. They concluded that the impact was well evidenced by entrepreneurial learning results (i.e., change of knowledge, skills, and attitude), the level of interest in entrepreneurship, entrepreneurial intention, and student and staff motivation [33]. The general impression is that entrepreneurial education does work; some meta-analysis research in this field has shown small positive effects of education in entrepreneurship on entrepreneurial intention [26,27], or on the intention to start a business [25], but there is no consensus on how to assess its effectiveness. In this work, the evaluation of effectiveness was carried out by presenting the students with a questionnaire, making them the protagonists of their training process, which corresponds to a model of teaching on demand [40] called "The demand model" which uses activities involving exploration, discussion, and experimentation. The teaching methods used for the acquisition of skills are fundamental to achieving success, as stated by [19]. The results obtained in [27] point to a high correlation between pre- and post-intention and this correlation does not change greatly with entrepreneurial intention and suggests other improved criteria such as entrepreneurial skills and performance. The survey presented in [28] concludes that there is a positive link between entrepreneurial education and entrepreneurial activity; the results of [29] confirm the effects on Spanish students' skills and the intention to create a business; in [30] the authors show evidence of positive effects in several countries, pointing out that it is more effective in entrepreneurship-hostile institutional environments; and the authors of $[8,31]$ show the positive effects of entrepreneurship programmes on the improvement of some skills. However, some authors find non-significant or negative effects. In [41] the authors find a mix of effects with high satisfaction and better learning efficacy, but the entrepreneurial intentions of students were not improved and the authors of [42] even claim that the effects of a programme on the intention to become an entrepreneur were negative.

There is evidence that a large variety of skills play an essential role in the process of becoming an entrepreneur [43,44], and some authors agree that entrepreneurial education should focus on the development of skills, attitudes, and practical training [45,46]. In [39] the authors afforded a general framework for teaching entrepreneurship based on an active, practical approach. However, no comprehensive set of entrepreneurial skills has yet emerged from the literature; the authors of [35] analyze the skills included in their own survey that compare the situation of young European higher education graduates; and the authors of [31] provide a core set of 13 entrepreneurial skills employing 
a Delphi methodology. According to the psychological literature, in [45] the authors established a set of seven entrepreneurial skills; five of them were selected by [47], as frequently associated with entrepreneurs in both theoretical and empirical research. A similar set of skills was previously used in the Caird test of enterprising tendency [48]. In [49] the authors defined seven entrepreneurial skills, which have been used by other authors [50], and that were found to be predictive of business ownership.

Regarding transversal employability skills, HEIs must ensure that students are prepared to handle and solve complex problems in an environment of uncertainty [51] and produce employable graduates that contribute to economic growth and sustainable development [52]. Some studies analyze the integration between higher education and job skills and the positive effects that it entails $[53,54]$. The European Commission [55] explains the connection between sustainable growth, education, and the labor market [56]: it is necessary to improve the performance of education systems to facilitate the entry of young people into the labor market; the acquisition of new skills that empower people and empower their job training and the best adaptation between labor supply and demand. In [57] the authors distinguish between professional skills, professional qualifications, and professional competences. Professional skills refer to the knowledge, skills, and aptitudes necessary for the realization of a certain profession. Professional qualification also requires flexibility and autonomy. On the other hand, professional competences include human, socio-political, planning, and work organization skills. All three cases refer to a series of values, attitudes, habits, aptitudes, and knowledge that are necessary for work development and professional efficiency [58-65]. Professional competences are related to suitability to perform a work activity and to solve problems with a sense of challenge, flexibility, understanding, motivation, creativity, and entrepreneurship [66].

Other authors [67-70] research the incorporation of transversal competences applied to the university sector; while other studies analyze the integration between higher education and job skills and the positive effects that it entails [53,54,71]. The Phoenix report of Future Work Skills H2020 [72] proposes the following skills as a basis for achieving success in the workplace: Creating meaning, social intelligence, original and adaptive thought, trans-cultural competence, literacy in new means of communication, transdisciplinary to understand concepts through multiple disciplines, developing a way of thinking in order to attain the desired results, cognitive load management, virtual collaboration as a member of a virtual team, computational thinking for transferring large quantities of data into abstract concepts and to understand data-based reasoning [73]. These skills should be acquired by university students for successful use in a real work context [55]. In [66] the authors conclude in their investigation that in Spain it is necessary to improve training for the true acquisition of transversal competences in unemployed people, such as team work, management in stressful situations, problem-solving, willingness to learn, self-initiative, verbal communication, and mastery of social networks. In summary, their main transversal competences to improve the employability of university graduates, extracted from the bibliographic review, are adaptability in stressful situations, teamwork, specific adaptability to contingencies, personal effectiveness, general adaptability to changes in the sector, identification of their own professional abilities, adaptation to the specific work context of the job, organization of work, autonomy, orientation to achievement or entrepreneurial spirit, learning capacity, relationships, negotiating capacity, problem resolution, communication, and responsibility.

In most studies of the international literature, some skill assessment techniques are gathered, such as the standardized competence assessment procedure [74], the CAT (Competency Assessment Tool) [75], the CBT (competencies-based training systems) [76], and the sustainable employability assessment tool [77], among others. The problem is that these tools only address some competencies, or only focus on the analysis of certain types of degree studies [14], not being applicable to others. Some authors also analyze another series of specific competencies that contribute to students entering the labor market successfully facing their first job, from the employer's point of view [78].

Considering the acquisition of transversal employability competencies incorporated in the curricular subjects there are not many evaluations from the point of view of the students. Generally, undergraduate students use some self-assessment techniques to measure competencies [79] such as 
the self-perceived employability scale (SPE) [80,81], however, there are investigations that emphasize the need for an objective measurement of their level of employability [79].

\section{Materials and Methods}

\subsection{The Research Background}

The TP was 12 weeks long, comprising six modules, with undergraduates from a variety of degrees (Business, Marketing, Tourism, Economics, Law, Advertising, Audiovisual Studies, History, Journalism, and Engineering) and was as close as possible to a real word situation, including entrepreneur and investor meetings. The students developed a business plan in teams that were set up at the beginning using group dynamics and according to their own business ideas. The teams worked under the supervision of a lecturer or consultant. The traditional "learning by doing" from the Entrepreneur Education Programmes was combined with traditional teaching, such as market analysis, marketing and financial plans, etc., according to [82]. There was a final assessment by a panel of professors and consultants of a business opportunity project, considering originality and viability. The best project in each edition received a prize and was presented to potential investors.

The TP started in 2013 with 130 students who performed an initial TP assessment (modules, teachers, and consultants). In 2014 and 2015, nine editions took place with 211 students (only 65\% of the applicants were admitted). The student success rate was also very high; $70 \%$ completing projects that were positively assessed by the experts.

\subsection{Methods and Sample}

At the end of the programme, the students were asked to assess the level of competencies acquired, both entrepreneurial and generic transversal competencies.

\subsubsection{Relevant competencies}

A nominal group technique was used to identify the relevant competencies. In the first stage, a group of seven academic entrepreneurship experts was set up to consider the relevant transversal employability competencies. Firstly, they selected skills that could be acquired by the students enrolled in the TP from the list of generic skills [16], grouped into three sections: instrumental, interpersonal, and systemic. Secondly, the participants discussed the skills that a member had included in the previous stage. This discussion concluded with an agreed generic skill list to be acquired (to a certain extent) from the TP. Table 1 shows the skills included in the students' survey.

Table 1. Generic skills [9].

\begin{tabular}{l} 
Panel (a) Instrumental Skills \\
\hline C1 Capacity of analysis and synthesis. \\
C2 Capacity of organization and planning. \\
C4 Grounding in basic knowledge of the profession. \\
C5 Oral and written communication in the student's native language. \\
C8 Information management skills (ability to retrieve and analyze information from different sources). \\
C9 Problem-solving. \\
C10 Decision-making. \\
\hline \multicolumn{1}{c}{ Panel (b) Interpersonal Skills } \\
\hline C12 Teamwork \\
\hline C19 Capacity to apply knowledge in practice. \\
C21 Capacity to learn. \\
C23 Capacity to generate new ideas (creativity). \\
C26 Ability to work autonomously. \\
C27 Project design and management. \\
C28 Initiative and entrepreneurial spirit. \\
C30 Will to succeed.
\end{tabular}


In the second stage, the same group of experts were provided with three lists of common entrepreneurial skills which are shown in Table $2[45,47,49]$. The focus group agreed that the entrepreneurial skills of [45] were the most closely linked to the TP. These potentially acquirable skills were included in the survey.

Table 2. Set of entrepreneurial skills.

\begin{tabular}{cccc}
\hline & Dada et al. [47] & Kirby [45] & Wagener et al. [49] \\
\hline Need for achievement (E1) & $X$ & $X$ & \\
Desire for autonomy (E2) & $X$ & $X$ & $X$ \\
Creativity and & $X$ & $X$ & $X$ \\
opportunism (E3) & $X$ & $X$ & $X$ \\
Risk-taking ability (E4) & $X$ & $X$ & \\
Locus of control (E5) & & $X$ & $X$ \\
Deviation & & $X$ & $X$ \\
Intuition & & & $X$ \\
Tolerance of ambiguity & & & $X$ \\
Self-efficacy & & & \\
Market orientation & & & \\
Leadership qualities & & & \\
\hline
\end{tabular}

Note: the entrepreneurial skills included in the questionnaire appear in bold.

\subsubsection{Questionnaire}

An anonymous questionnaire was divided into three parts. The first included personal student data: gender, age, course, degree, average academic grade, whether or not the student had practical experience working in a company, entrepreneurial experience, or family members that were entrepreneurs.

The second and third part of the questionnaire required the students to assess the degree of acquisition (i.e., how much they had improved) on a Likert scale from 1 to 6 (1 represented minimum acquisition and 6 maximum acquisition) of each generic skill (second) and entrepreneurial skills (third) after the TP.

\subsubsection{Population}

The population included the students that participated successfully in the nine editions; they were interviewed after the evaluation of their projects. Notice that our population had a selection bias; however, it did not affect the results of the study, as the students whose entrepreneurship preference or ability was high would probably enroll in entrepreneurship programmes [83]. The population was comprised of 148 students. A total of 107 valid questionnaires were obtained, which gives us a response rate of $72.3 \%$. The margin of error was $95 \%$ the confidence was \pm 0.05 .

\section{Results}

\subsection{The Sample}

Of the 107 students, $55.66 \%$ were male and $44.34 \%$ female. The distribution of the average academic grades was $40.6 \%$ pass, $58.5 \%$ good, and $0.9 \%$ outstanding. A total of $68.87 \%$ of the students had experience in the labor market (internship or work) and $64.15 \%$ had been in direct contact with entrepreneurship through a family member or had direct experience. As far as age is concerned, $16.98 \%$ of the sample were students over the age of 25 and $83.02 \%$ were 25 or younger.

\subsection{Generic Instrumental Skills}

Table 3 shows the descriptive statistics of the students' assessment of the degree of acquisition of each generic instrumental skill. The average acquisition of each of these skills appears to be different and the equality of the averages was therefore tested. The ANOVA statistic rejected the hypothesis 
that the average acquisition was the same in all instrumental skills. Therefore, we can conclude that the average acquisition was statistically different.

Table 3. Descriptive statistics of the acquisition of generic instrumental skills from the Training Programme (TP).

\begin{tabular}{|c|c|c|c|c|c|c|c|}
\hline & $\mathrm{C} 1$ & $\mathrm{C} 2$ & $\mathrm{C} 4$ & $\mathrm{C} 5$ & $\mathrm{C} 8$ & C9 & $\mathrm{C} 10$ \\
\hline \multicolumn{8}{|c|}{ Panel (a) Descriptive statistics } \\
\hline Average & 4.133 & 4.429 & 4.308 & 3.388 & 3.905 & 4.267 & 4.457 \\
\hline Median & 4 & 5 & 4 & 3 & 4 & 4 & 5 \\
\hline Standard deviation & 1.066 & 0.929 & 1.080 & 1.567 & 1.312 & 1.171 & 1.118 \\
\hline \multicolumn{8}{|c|}{ Panel (b) Average equality test according to student gender } \\
\hline Men & 4.051 & 4.305 & 4.259 & 3.439 & 4.017 & 4.271 & 4.492 \\
\hline Women & 4.239 & 4.587 & 4.370 & 3.326 & 3.761 & 4.261 & 4.413 \\
\hline$t$-statistic ( $p$-value) & $(0.372)$ & $(0.123)$ & $(0.605)$ & $(0.719)$ & $(0.323)$ & $(0.965)$ & $(0.723)$ \\
\hline \multicolumn{8}{|c|}{ Panel (c) Average equality test according to student age } \\
\hline Students over 25 & 4 & 4.111 & 4.333 & 3.647 & 4.111 & 4.056 & 4.389 \\
\hline Students under 25 & 4.161 & 4.494 & 4.302 & 3.337 & 3.862 & 4.310 & 4.471 \\
\hline$t$-statistic ( $p$-value) & $(0.592)$ & $(0.112)$ & $(0.912)$ & $(0.459)$ & $(0.466)$ & $(0.403)$ & $(0.778)$ \\
\hline \multicolumn{8}{|c|}{ Panel (d) Average equality test according to overall student grade } \\
\hline Good/outstanding & 4.095 & 4.476 & 4.238 & 3.365 & 3.889 & 4.286 & 4.508 \\
\hline Pass & 4.190 & 4.357 & 4.415 & 3.425 & 3.929 & 4.238 & 4.381 \\
\hline$t$-statistic ( $p$-value) & $(0.656)$ & $(0.523)$ & $(0.418)$ & $(0.851)$ & $(0.880)$ & $(0.839)$ & $(0.571)$ \\
\hline \multicolumn{8}{|c|}{ Panel (e) Average equality test according to previous experience in the labor market or not } \\
\hline Yes & 4.123 & 4.384 & 4.417 & 3.380 & 3.862 & 4.274 & 4.466 \\
\hline No & 4.156 & 4.531 & 4.063 & 3.406 & 4.000 & 4.250 & 4.438 \\
\hline$t$-statistic ( $p$-value) & $(0.885)$ & $(0.456)$ & $(0.123)$ & $(0.938)$ & $(0.625)$ & $(0.924)$ & $(0.906)$ \\
\hline \multicolumn{8}{|c|}{ Panel (f) Average equality test according to previous student contact with entrepreneurship or not } \\
\hline Yes & 4.134 & 4.433 & 4.288 & 3.194 & 3.925 & 4.313 & 4.537 \\
\hline No & 4.132 & 4.421 & 4.342 & 3.750 & 3.868 & 4.184 & 4.316 \\
\hline$t$-statistic ( $p$-value) & $(0.990)$ & $(0.951)$ & $(0.807)$ & $(0.086)$ & $(0.832)$ & $(0.589)$ & $(0.332)$ \\
\hline
\end{tabular}

Note: acquisition of skill on a Likert scale from 1 (minimum) to 6 (maximum acquisition). The $p$-value of the $t$-statistic was used to test the hypothesis of equality of average acquisition of the skill in both groups. * indicates rejection of the null hypothesis.

The skills considered by the students as the least acquired from the TP were "oral and written communication in the student's native language" (C5) and "information management skills (ability to retrieve and analyze information from different sources)" (C8). It was observed that skill C5 was clearly lower than the others, indicating that the TP did not strengthen the skill. As a Likert scale from 1 to 6 was used for assessment in the questionnaire, the rating achieved by skill C 5 of 3.39 was very low. In addition, there was discrepancy amongst the students (the dispersion is 1.57). This result surprised the professors involved in the TP. Given that the students gave a presentation of their project before a panel of experts at the end of the TP, they expected a higher assessment. C8 was also poorly rated in comparison to the other skills. Although the final project required the ability to retrieve and analyze information from different sources, students did not perceive a special contribution to achieving this skill. It is likely that they compared the acquisition of the skill during the TP with modules in their own degrees.

On the other hand, the instrumental skills that were most highly acquired from the $\mathrm{TP}$, in the opinion of students, were "decision-making" (C10) and "capacity for organization and planning" (C2). These skills, with average scores of 4.46 and 4.43 , respectively, indicate that they were acquired substantially in the TP. This result is in line with [35], who detected that "leadership" and "taking responsibility and decisions" are the two skills acquired by entrepreneurs after graduation that enable a distinction between entrepreneurs and other graduates. Additionally, the authors of [35] found that the most required skills in entrepreneurship (according to their entrepreneur's survey) were "working 
independently", "taking responsibility and decisions", and "problem-solving ability". These authors consider that $\mathrm{C} 10$ can be considered as an entrepreneurial skill, which justifies its high assessment after the TP. For the same reason, the high rating achieved by the "problem solving" skill (C9) in the TP can be justified, which holds third place in the list of required competencies according to [35]. Along the same lines, the "capacity for organization and planning" (C2) was also highly achieved. In [35] the authors showed that "planning, coordinating, and organizing" is a highly relevant competence for entrepreneurs, however for the self-employed it is not so important.

Table 3 also shows the average degree of acquisition of each skill as rated by the students, according to different criteria: gender (Panel b), age (c), academic grade (d), experience in the labor market (e) and prior experience in entrepreneurship (f). We also included a statistic (with its $p$-value) to test the equality of the averages of the groups of students classified according to each of these criteria. In no case was the hypothesis of average equality rejected, which means that the average acquisition of the skill in the TP did not vary when the students were classified according to the different criteria.

\subsection{Generic Interpersonal and Systemic Skills}

Table 4 shows the descriptive statistics of the acquisition of generic interpersonal and systemic skills from the TP. As in the previous section, the ANOVA statistic rejects the null hypothesis that the average acquisition is the same in all systemic skills (C19, C21, C27, and C28), thus indicating that the average acquisition was statistically different.

Table 4. Descriptive statistics of the acquisition of generic interpersonal and systemic skills from the TP.

\begin{tabular}{|c|c|c|c|c|c|c|}
\hline & C12 & C19 & $\mathrm{C} 21$ & $\mathrm{C} 27$ & $\mathrm{C} 28$ & $\mathrm{C} 30$ \\
\hline \multicolumn{7}{|c|}{ Panel (a) Descriptive statistics } \\
\hline Average & 4.663 & 4.443 & 4.533 & 4.528 & 5.009 & 4.906 \\
\hline Median & 5 & 5 & 5 & 5 & 5 & 5 \\
\hline Standard deviation & 1.359 & 0.947 & 1.127 & 1.148 & 1.028 & 1.183 \\
\hline \multicolumn{7}{|c|}{ Panel (b) Average equality test according to student gender } \\
\hline Men & 4.579 & 4.475 & 4.517 & 4.525 & 5.017 & 5.000 \\
\hline Women & 4.773 & 4.404 & 4.553 & 4.532 & 5.000 & 4.787 \\
\hline$t$-statistic ( $p$-value) & $(0.480)$ & $(0.706)$ & $(0.872)$ & $(0.977)$ & $(0.933)$ & $(0.390)$ \\
\hline \multicolumn{7}{|c|}{ Panel (c) Average equality test according to student age } \\
\hline Students over 25 & 4 & 4.611 & 4.889 & 4.333 & 5.167 & 4.889 \\
\hline Students under 25 & 4.788 & 4.409 & 4.460 & 4.568 & 4.977 & 4.960 \\
\hline$t$-statistic ( $p$-value) & $(0.033)^{*}$ & $(0.412)$ & $(0.142)$ & $(0.432)$ & $(0.479)$ & $(0.861)$ \\
\hline \multicolumn{7}{|c|}{ Panel (d) Average equality test according to overall student grade } \\
\hline Good/outstanding & 4.825 & 4.444 & 4.540 & 4.460 & 4.968 & 4.973 \\
\hline Pass & 4.395 & 4.442 & 4.524 & 4.628 & 5.070 & 4.758 \\
\hline$t$-statistic ( $p$-value) & $(0.123)$ & $(0.989)$ & $(0.944)$ & $(0.463)$ & $(0.620)$ & $(0.389)$ \\
\hline \multicolumn{7}{|c|}{ Panel (e) Average equality test according to previous experience in the labor market or not } \\
\hline Yes & 4.662 & 4.425 & 4.507 & 4.479 & 5.014 & 4.971 \\
\hline No & 4.667 & 4.485 & 4.594 & 4.636 & 5.000 & 4.789 \\
\hline$t$-statistic ( $p$-value) & $(0.987)$ & $(0.764)$ & $(0.718)$ & $(0.517)$ & $(0.950)$ & $(0.453)$ \\
\hline \multicolumn{7}{|c|}{$\begin{array}{l}\text { Panel (f) Average equality test according to previous student contact with entrepreneurship } \\
\text { or not }\end{array}$} \\
\hline Yes & 4.667 & 4.471 & 4.478 & 4.544 & 5.103 & 5.278 \\
\hline No & 4.571 & 4.395 & 4.632 & 4.500 & 4.842 & 4.830 \\
\hline$t$-statistic ( $p$-value) & $(0.974)$ & $(0.695)$ & $(0.504)$ & $(0.851)$ & $(0.212)$ & $(0.144)$ \\
\hline
\end{tabular}

Note: see note in Table 3. 
Firstly, it is important to point out that the average acquisition of interpersonal and systemic skills was higher than instrumental skills. This result was expected, given the rapid consensus obtained in focal group techniques that these skills were potentially acquirable.

Secondly, as expected, the systemic skill of "initiative and entrepreneurial spirit" (C28) obtained a high average assessment, indicating that the TP substantially contributed to acquiring this skill. In addition, it was the generic skill that reached the highest degree of acquisition according to the students. Given the close link between skill C28 and the overall objective of the TP, this result was expected. It is followed by the "will to succeed" (C30), which obtained a high average assessment, thus indicating that the TP substantially contributed to achieving the skill. It should be observed that certain authors [84] consider C30 to be an entrepreneurial skill. The meta-analysis of [84] finds that "achievement motivation" was significantly correlated with both the choice of an entrepreneurial career and entrepreneurial performance.

Thirdly, the remaining (interpersonal and systemic) skills in Table 4 show very similar averages. The ANOVA statistic does not reject the null hypothesis that the average acquisition is the same in skills $\mathrm{C} 12, \mathrm{C} 19, \mathrm{C} 21$, and C27, thus indicating that their average assessment was statistically equal. Therefore, according to the students, the TP contributed equally to achieving "teamwork" skills, the "capacity for applying knowledge in practice", and the "capacity to learn".

Finally, a test was carried out to determine the existence of differences in terms of average acquisition of skills when the students were classified according to gender, age, overall academic grade, and whether they had previous experience in the labor market or entrepreneurship. The empirical evidence showed that there were no differences in any of the interpersonal and systemic skills (as in instrumental skills), except for interpersonal skill C12. Panel (c) shows that the $t$-statistic rejects the hypothesis of average equality of the "teamwork" skill (C12) in students over the age of 25, in relation to those under 25, which indicates that the students under 25 perceived higher acquisition of this skill after taking part in the TP.

\subsection{Entrepreneurial Skills}

Table 5 analyzes the acquisition of entrepreneurial skills defined by [47]. Panel (a) shows that the average acquisition of entrepreneurial skills, in the opinion of the students, was around 4.5 out of 6. The ANOVA statistic shows that the average acquisition of these skills was statistically different. Nevertheless, when we exclude the "risk-taking ability" skill (E4), the ANOVA statistic indicates, according to the students, that the acquisition of the skills "need for achievement" (E1), "desire for autonomy" (E2), "creativity and opportunism" (E3), and "locus of control" (E5) resulting from the TP was statistically equal. The skill "risk-taking ability", which was attained to a lesser extent in the TP is one of the skills identified by [51] as those that set entrepreneurs apart from small business owners in the hospitality industry (in addition to independence, ambiguity tolerance, and leadership).

Notice that in spite of the objective of the TP, the acquisition of these skills linked to entrepreneurship was similar to interpersonal and systemic skills. In fact, if we eliminate skills E4 (lowest score in entrepreneurial skills) and C28 (the highest rated systemic skill), the ANOVA test indicates that the assessment of the rest (C12, C19, C21, C27, E1, E2, E3, and E5) was statistically equal.

Table 5 also shows the average acquisition of each of these skills when classified by students. In this case, unlike what occurred with the generic skills, the average levels of acquisition of entrepreneurial skills were shown to be statistically different for certain classifications of students. In particular, the $t$-statistic rejects the hypothesis of equality of the average acquisition of skill E4 by students with a pass grade in relation to those with a good or outstanding grade. This indicates that students with a pass grade consider that the TP contributed more to acquiring "risk-taking ability" than students with a higher grade (Panel d). It can also be observed in (Panel c) that students over the age of 25 perceived a higher average acquisition of this skill after taking part in the TP. It is important to recall that this is the skill that, according to the general opinion, was least achieved by the TP. It is therefore 
an entrepreneurial skill with a lower acquisition, on which the opinions of acquisition differ according to the classification.

Table 5. Descriptive statistics of the acquisition of entrepreneurial skills from the TP.

\begin{tabular}{|c|c|c|c|c|c|}
\hline & E1 & E2 & E3 & E4 & E5 \\
\hline \multicolumn{6}{|c|}{ Panel (a) Descriptive statistics } \\
\hline Average & 4.610 & 4.462 & 4.619 & 4.212 & 4.429 \\
\hline Median & 5 & 5 & 5 & 4 & 4 \\
\hline Standard deviation & 1.114 & 1.034 & 1.113 & 1.030 & 1.099 \\
\hline \multicolumn{6}{|c|}{ Panel (b) Average equality test according to student gender } \\
\hline Men & 4.729 & 4.576 & 4.712 & 4.345 & 4.610 \\
\hline Women & 4.457 & 4.319 & 4.500 & 4.043 & 4.196 \\
\hline$t$-statistic ( $p$-value) & $(0.216)$ & $(0.205)$ & $(0.335)$ & $(0.139)$ & $(0.055) *$ \\
\hline \multicolumn{6}{|c|}{ Panel (c) Average equality test according to student age } \\
\hline Students over 25 & 4.889 & 4.889 & 4.833 & 4.611 & 4.778 \\
\hline Students under 25 & 4.552 & 4.375 & 4.575 & 4.128 & 4.356 \\
\hline$t$-statistic ( $p$-value) & $(0.244)$ & $(0.054) *$ & $(0.372)$ & $(0.070) *$ & $(0.140)$ \\
\hline \multicolumn{6}{|c|}{ Panel (d) Average equality test according to overall student grade } \\
\hline Good or outstanding & 4.492 & 4.365 & 4.540 & 4.048 & 4.317 \\
\hline Pass & 4.786 & 4.605 & 4.738 & 4.463 & 4.595 \\
\hline$t$-statistic ( $p$-value) & $(0.187)$ & $(0.244)$ & $(0.373)$ & $(0.044) *$ & $(0.206)$ \\
\hline \multicolumn{6}{|c|}{ Panel (e) Average equality test according to previous experience in the labor market or not } \\
\hline Yes & 4.644 & 4.534 & 4.685 & 4.139 & 4.397 \\
\hline No & 4.531 & 4.303 & 4.469 & 4.375 & 4.500 \\
\hline$t$-statistic ( $p$-value) & $(0.636)$ & $(0.289)$ & $(0.362)$ & $(0.283)$ & $(0.662)$ \\
\hline \multicolumn{6}{|c|}{$\begin{array}{l}\text { Panel (f) Average equality test according to previous student contact with } \\
\text { entrepreneurship or not }\end{array}$} \\
\hline Yes & 4.597 & 4.485 & 4.532 & 4.299 & 4.612 \\
\hline No & 4.632 & 4.421 & 4.684 & 4.054 & 4.105 \\
\hline$t$-statistic ( $p$-value) & $(0.879)$ & $(0.761)$ & $(0.654)$ & $(0.249)$ & $(0.023) *$ \\
\hline
\end{tabular}

Note: see note in Table 3.

The same result was observed in skill (E2) "desire of autonomy" in relation to student age (Panel c). Again, the students over the age of 25 had higher levels of average acquisition of E2 after taking part in the TP, as indicated by the $t$-statistic.

Additionally, men showed a higher average acquisition of "locus of control" (E5) after taking part in the TP than women (Panel b), and students with previous contact with entrepreneurship (either directly or indirectly) had higher levels of average acquisition of E5 than those with contact with entrepreneurship for the first time in the TP.

Our results (except for the "locus of control" skill) are in line with [27] who found a non-significantly different relationship between entrepreneurship education and entrepreneurial intention, in relation to gender or an entrepreneurial family background, and with [85] who found that students' age and their general level of entrepreneurship-related knowledge influence the gaps in knowledge and competencies.

\subsection{Reliability Analysis}

Finally, the objective was to check whether the assessment of the acquisition of skills by the students was reliable. We therefore studied whether successive assessments (throughout the survey) made by the students of the acquisition of skills coincided. The analysis was carried out on two specific skills, given that there are two that are generic and entrepreneurial at same time and were included in 
the questionnaire in their respective sections. Generic skill C23 coincided with the E3 entrepreneurial skill; and skill C26 with skill E2. The authors of [16] include them in their list of generic skills that should be the result of an educational process and in [51] the authors include them in the set of an entrepreneur's basic skills (Tables 1 and 2).

The students therefore assessed the same skill in two different sections of the survey with their respective names. Given that they are actually the same skill, if the assessment was reliable, the degree of correlation would be high. We therefore calculated two Pearson coefficients. The correlation coefficient between skills C23 and E3 was 0.7. For skills C26 and E2, the coefficient was also 0.7. This result shows a high degree of reliability in the assessment of the acquisition of skills by the students.

\section{Discussion, Conclusions, and Limitations}

The Sustainable Development Agenda considers that education should enhance the development of relevant skills for employment and entrepreneurship, especially at higher levels of education. Therefore, HEIs have a relevant role to play in forming employable graduates who are capable of resolving complex problems in an uncertain environment and contribute to economic growth and sustainable development. Higher education for entrepreneurship and employability in the labor market should promote not only the acquisition of professional skills, but also personal skills that can support these abilities [14].

This study analyzes the acquisition of entrepreneurial skills and employability transversal competencies (university graduates) resulting from a TP, which was designed as an entrepreneurship education programme with the purpose of providing students with entrepreneurial skills $[45,47,49]$ and specific skills referred to in the literature as employable transversal or generic [11-18]. Mix-method learning was used in the TP in similar way to [19]. The TP combines training in entrepreneurship with traditional teaching for degree students and it ended with the preparation of business plans in groups under the supervision of a lecturer or consultant. The best projects received a prize and were presented to potential investors. At the end of the course, the students assessed their acquisition of skills by means of a questionnaire designed according to the nominal group technique.

The most relevant conclusions are, first, generic instrumental skills are acquired to a lesser degree than generic interpersonal and systemic skills. This result is most likely due to these skills being developed through many subjects in their respective degrees. Therefore, they perceived a lower acquisition from the TP in relative terms. In the group of generic instrumental skills, those that showed the highest degree of acquisition ("decision-making" and "capacity for organization and planning") could be defined as both employable transversal and entrepreneurial skills, given that other authors conclude that they are required skills of entrepreneurs [35].

Secondly, the evidence shows that the acquisition of certain interpersonal and systemic generic skills is similar to that of entrepreneurial skills. Note that there are four skills in education that the literature defines as generic systemic skills, whereas they are defined as entrepreneurial skills in entrepreneurship literature. In fact, two skills were included simultaneously in both groups (generic and entrepreneurial skills) in the questionnaire, and the duplicated assessment provided an indication of the reliability of the answers.

Thirdly, only entrepreneurial skills were acquired at different levels by different groups of students. Specifically, (i) students with good or outstanding grades perceived lower acquisition of "risk-taking ability"; (ii) students over the age of 25 perceived a higher degree of "risk-taking ability" and "desire for autonomy"; (iii) men showed a higher degree of acquisition of "locus of control" than women; and (iv) students that had previous contact with entrepreneurship achieved a higher degree of acquisition of "locus of control" than those that came into contact with entrepreneurship for the first time in the TP. Note that acquiring these skills was the main objective of the students enrolled in the TP, since these abilities are not provided in the compulsory subjects in university degrees. In addition, certain factors, such as aversion to risk and student age could be behind the different perceptions of "risk-taking ability" by students over and under the age of 25 . The fact that students that had contact 
with entrepreneurship prior to the TP perceived a higher average acquisition of the locus of control skill (ability to control results) could be because their previous level in this skill was higher than that of their colleagues.

Our results are in line with other works that also observe effects on competences or skills [8,19,29-31] which conclude that training entrepreneurial competences improves the level of employability of university graduates. They are also consistent with other studies that show other positive effects, as shown by the surveys in $[26,27]$.

Overall, this work provides new evidence for the positive effects of entrepreneurship and employee education in a university programme (combining training and traditional teaching methods) in terms of the acquisition of skills. The results are important, as this is the first investigation to analyze the efficiency of a TP from a dual perspective: the acquisition of entrepreneurial skills and transversal employability competencies by university graduates. The evidence shows that students acquire both types of skills simultaneously but at different levels. Our results indicate that some of the transversal skills pursued in European University curricula (following the convergence process towards a common European Higher Education Area) could be acquired by a TP together with entrepreneurial competencies.

An important suggestion based on the evidence presented, given that education in entrepreneurship is more successful at a university level (European Commission, 2015) and that European university graduates have low levels of education in entrepreneurship (European Commission, 2008) would be to integrate TP into university curricula as compulsory subjects. This would fulfil a dual objective: acquisition of transversal generic competencies that all graduates should have, especially for employability, and the acquisition of basic entrepreneurial skills, which could help to generate positive environments aimed at promoting entrepreneurship in the EU.

The employability of graduates has been an important focus of the Bologna Process from the very beginning and continues to be so, as the authors of [65] point out. In 2015, the Yerevan Communiqué stated that fostering the employability of graduates during their working lives in quickly changing labor markets is a major goal for European Higher Education, and HEIs should strengthen agreements with companies in order to implement TP with a good balance between theoretical and practical components, fostering the entrepreneurship skills of students in graduate career development.

This TP is a clear example of how, faced with a rigid university system, universities are looking for alternatives to be able to cover these needs, with non-mandatory TPs. Given the effectiveness of the TP, it would be desirable to count on the determination and conviction of university managers to include it within the framework of the curricula.

Finally, in [86] the authors analyze the European Higher Education Area (EHEA) median of unemployment rates and show that the higher the education level, the lower the unemployment. This result is also valid in Spain, but the decrease in the unemployment rate with high education is lower (the decrease is 23\% at Graduate and $44 \%$ at Master-level, while the EHEA median decreases are $33 \%$ and $47 \%$, respectively). Maybe we could converge with the EHEA median fostering the entrepreneurship and innovation skills of students via TPs in the university.

This work presents a limitation that provides a clear agenda for future research. The results are limited to a TP in a Spanish university. As a consequence, the findings cannot be generalized to different geographical contexts. However, our paper's original contribution could lead to analyzing the effectiveness of other TPs in other universities with a dual perspective, i.e., considering both kinds of competencies simultaneously. Finally, our TP is a dynamic programme that incorporates innovative teaching methodologies with the aim of achieving greater acquisition of skills. Therefore, our agenda for future research includes the analysis of the effect of such teaching methodologies on the acquisition of competences.

Author Contributions: The authors have contributed equally to this work. All authors have read and agree to the published version of the manuscript. 
Funding: The Training Programme for developing employability competencies and entrepreneurial skills received funding from Obra Social La Caixa.

Acknowledgments: The authors want to thank the enrolled students for their collaboration in the training programme and in this study and the academic experts of the TP for their cooperation.

Conflicts of Interest: The authors declare no conflict of interest.

\section{References}

1. The United Nations (UN). Transforming Our World: The 2030 Agenda for Sustainable Development; UN: New York, NY, USA, 2015; Available online: http://www.un.org/ga/search/view_doc.asp?symbol=A/RES/70/1\&Lang=E (accessed on 10 June 2019).

2. United Nations. Sustainable Development Goals. 2019. Available online: https://www.un.org/ sustainabledevelopment/education/ (accessed on 16 October 2019).

3. United Nations Educational, Scientific and Cultural Organization (UNESCO). Education for Sustainable Development Goals: Learning Objectives; UNESCO: Paris, France, 2017; Available online: http://unesdoc.unesco. org/images/0024/002474/247444e.pdf (accessed on 16 May 2019).

4. Thurik, A.R.; Stam, E.; Audretsch, D.B. The rise of the entrepreneurial economy and the future of dynamic capitalism. Technovation 2013, 33, 302-310. [CrossRef]

5. Guerrero, M.; Urbano, D. Evolution and development of entrepreneurial universities: A resources and capabilities perspective. Int. J. Educ. Res. Dev. 2014, 30, 30-45. Available online: https://pdfs.semanticscholar. org/4990/23c6db50a6cc446bad3d45e1ec3d69e03170.pdf (accessed on 15 May 2019).

6. Guerrero, M.; Cunningham, J.A.; Urbano, D. Economic impact of entrepreneurial universities' activities: An exploratory study of the United Kingdom. Res. Policy 2015, 44, 748-764. [CrossRef]

7. Rauch, A.; Hulsink, W. Putting entrepreneurship education where the intention to act lies: An investigation into the impact of entrepreneurship education on entrepreneurial behavior. Acad. Manag. Learn. Educ. 2015, 14, 187-204. [CrossRef]

8. Alcaraz-Rodriguez, R.; Alvarez, M.; Villasana, M. Developing entrepreneurial competences in students in the life sciences: The Lifetech Ad-Venture program. Horizon 2014, 22, 182-191. [CrossRef]

9. Dickson, P.H.; Solomon, G.T.; Weaver, K.M. Entrepreneurial selection and success: Does education matter? J. Small Bus. Enterp. Dev. 2008, 15, 239-258. [CrossRef]

10. European Union Commission. Entrepreneurship Education: A road to success. A Compilation of Evidence on the Impact of Entrepreneurship Education Strategies and Measures; Publications Office of the European Union: Brussels, Belgium, 2015; Available online: https://ec.europa.eu/social/BlobServlet?docId=7124\&langId=en (accessed on 10 June 2019).

11. European Union Commission. Transferability of Skills across Economic Sectors; European Union Commission, 2011; Available online: https://ec.europa.eu/social/BlobServlet?docId=7124\&langId=en (accessed on 5 June 2019).

12. UNESCO International Bureau of Education. IBE Glossary of Curriculum Terminology; UNESCO International Bureau of Education: Geneva, Switzerland, 2013; Available online: http://www.ibe.unesco.org/ (accessed on 10 June 2019).

13. OECD/KRIVET. Integrated Use of Occupational and Personal Skills for Lifelong Vocational Education in Korea; OECD/KRIVET, 2012; Available online: http://www.oecd.org/officialdocuments/publicdisplaydocumentpdf/ ?cote=EDU/EDPC/VET\%282012\%291\&docLanguage=En (accessed on 10 June 2019).

14. Gabor, M.R.; Blaga, P.; Matis, C. Supporting Employability by a Skills Assessment Innovative Tool-Sustainable Transnational Insights from Employers. Sustainability 2019, 11, 3360. [CrossRef]

15. World Economic Forum (WEF). The Future of Jobs Report 2018; World Economic Forum (WEF), 2018; Available online: http://www3.weforum.org/docs/WEF_Future_of_Jobs_2018.pdf (accessed on 15 November 2019).

16. González, J.; Wagenaar, R. Tuning Educational Structures in Europe; Final Report, Phase One; Deusto University: Bilbao, Spain, 2003; Available online: http://tuningacademy.org/wp-content/uploads/2014/02/TuningEUI_ Final-Report_EN.pdf (accessed on 15 November 2019).

17. European Union. Sustainable Development in the European Union, Monitoring Report on Progress towards the SDGS in an EU Context 2017; European Union, 2017; Available online: https://ec.europa.eu/eurostat/ documents/3217494/8461633/KS-04-17-780-EN-N.pdf (accessed on 16 August 2019). 
18. European Union. European Policy Cooperation (ET 2020 Framework) 2019; European Union, 2019; Available online: https://ec.europa.eu/education/policies/european-policy-cooperation/et2020-framework (accessed on 16 October 2019).

19. Iglesias-Sánchez, P.P.; Jambrino-Maldonado, C.; de las Heras-Pedrosa, C. Training Entrepreneurial Competences with Open Innovation Paradigm in Higher Education. Sustainability 2019, 11, 4689. [CrossRef]

20. O'Leary, S. Impact of entrepreneurship teaching in higher education on the employability of scientists and engineers. Ind. High. Educ. 2012, 26, 431-442. [CrossRef]

21. Liñán, F. Skill and value perceptions: How do they affect entrepreneurial intentions? Int. Entrep. Manag. J. 2008, 4, 257-272. [CrossRef]

22. Lazear, E.P. Balanced skills and entrepreneurship. Am. Econ. Rev. 2004, 94, 208-211. [CrossRef]

23. Karimi, S.; Biemans, H.J.; Lans, T.; Aazami, M.; Mulder, M. Fostering students' competence in identifying business opportunities in entrepreneurship education. Innov. Educ. Teach. Int. 2016, 53, 215-229. [CrossRef]

24. Gielnik, M.M.; Oyugi, J. Action and action-regulation in entrepreneurship: Evaluating a student training for promoting entrepreneurship. Acad. Manag. Learn. Educ. 2015, 14, 69-94. [CrossRef]

25. Sánchez-Escobedo, M.; Díaz-Casero, J.C.; Hernández-Mogollón, R.; Postigo-Jiménez, M.V. Perceptions and attitudes towards entrepreneurship. An analysis of gender among university students. Int. Entrep. Manag. J. 2011, 7, 443-463. [CrossRef]

26. Martin, B.C.; McNally, J.J.; Kay, M.J. Examining the formation of human capital in entrepreneurship: A meta-analysis of entrepreneurship education outcomes. J. Bus. Ventur. 2013, 28, 211-224. [CrossRef]

27. Bae, T.J.; Qian, S.; Miao, C.; Fiet, J.O. The relationship between entrepreneurship education and entrepreneurial intentions: A meta-analytic review. Entrep. Theory Pract. 2014, 38, 217-254. [CrossRef]

28. Raposo, M.; do Paço, A. Entrepreneurship education: Relationship between education and entrepreneurial activity. Psicothema 2011, 23, 453-457.

29. Sánchez, J.C. The impact of an entrepreneurship education program on entrepreneurial competencies and intention. J. Small Bus. Manag. 2013, 51, 447-465. [CrossRef]

30. Walter, S.G.; Block, J.H. Outcomes of entrepreneurship education: An institutional perspective. J. Bus. Ventur. 2016, 31, 216-233. [CrossRef]

31. Morris, M.H.; Webb, J.W.; Fu, J.; Singhal, S. A Competency-Based Perspective on Entrepreneurship Education: Conceptual and Empirical Insights. J. Small Bus. Manag. 2013, 51, 352-369. [CrossRef]

32. Beyhan, B.; Findik, D. Student and graduate entrepreneurship: Ambidextrous universities create more nascent entrepreneurs. J. Technol. Transf. 2016, 43, 1346-1374. [CrossRef]

33. European Union Commission. Best Procedure Project: Entrepreneurship in Higher Education, Especially in Non-Business Studies. Final Report of the Expert Group; European Union Commission, 2008; Available online: https://ec.europa.eu/growth/content/final-report-expert-group-entrepreneurship-higher-educationespecially-within-non-business-0_en (accessed on 16 October 2019).

34. NIRAS Consultants. Survey of Entrepreneurship in Higher Education in Europe. Fora E Econ; NIRAS Consultants, 2008; Available online: http://ec.europa.eu/enterprise/policies/sme/files/support_measures/ training_education/highedsur (accessed on 16 October 2019).

35. Martínez, D.; Mora, J.G.; Vila, L.E. Entrepreneurs, the Self-employed and Employees amongst young European higher education Graduates. Eur. J. Educ. 2007, 42, 99-117. [CrossRef]

36. Solomon, G.T.; Duffy, S.; Tarabishy, A. The state of entrepreneurship education in the United States: A nationwide survey and analysis. Int. J. Entrep. Educ. 2002, 1, 65-86. [CrossRef]

37. Pittaway, L.; Cope, J. Entrepreneurship Education: A Systematic Review of the Evidence. Int. Small Bus. J. 2007, 25, 479-510. [CrossRef]

38. Pittaway, L.; Edwards, C. Assessment: Examining practice in entrepreneurship education. Edu. Train. 2012, 54, 778-800. [CrossRef]

39. Neck, H.M.; Greene, P. Entrepreneurship Education: Know Worlds and New Frontiers. J. Small Bus. Manag. 2011, 49, 55-70. [CrossRef]

40. Bechard, J.P.; Gregoire, D. Understanding teaching' models in entrepreneurship for higher education. In The Dynamics of Learning Entrepreneurship in a Cross-Cultural University Context; Kyro, P., Carrier, C., Eds.; Faculty of Education, University of Tampere: Tampere, Finland, 2005; pp. 104-134. Available online: http: //expertise.hec.ca/chaire_entrepreneuriat/wp-content/uploads/2005-19-utmentrepreneurship.pdf. (accessed on 13 January 2020). 
41. Chen, S.C.; Hsiao, H.C.; Chang, J.C.; Chou, C.M.; Chen, C.P.; Shen, C.H. Can the entrepreneurship course improve the entrepreneurial intentions of students? Int. Entrep. Manag. J. 2015, 11, 557-569. [CrossRef]

42. Oosterbeek, H.; van Praag, M.; Ijsselstein, A. The impact of entrepreneurship education on entrepreneurship skills and motivation. Eur. Econ. Rev. 2010, 54, 442-454. [CrossRef]

43. Lans, T.; Verstegen, J.; Mulder, M. Analysing, pursuing and networking: Towards a validated three-factor framework for entrepreneurial competence from a small firm perspective. Int. Small Bus. J. 2011, 29, 695-713. [CrossRef]

44. Man, T.W.; Lau, T.; Chan, K.F. The competitiveness of small and medium enterprises: A conceptualization with focus on entrepreneurial competencies. J. Bus. Ventur. 2002, 17, 123-142. [CrossRef]

45. Kirby, D.A. Entrepreneurship education: Can business schools meet the challenge? Educ. Train. 2004, 46, 510-519. [CrossRef]

46. Rasmussen, E.A.; Sørheim, R. Action-based entrepreneurship education. Technovation 2006, 26, $185-194$. [CrossRef]

47. Dada, O.; Watson, A.; Kirby, D. Entrepreneurial tendencies in franchising: Evidence from the UK. J. Small Bus. Enterp. Dev. 2015, 22, 82-98. [CrossRef]

48. Caird, S. Testing enterprising tendency in occupational groups. Br. J. Manag. 1991, 2, 177-186. [CrossRef]

49. Wagener, S.; Gorgievski, M.; Rijsdijk, S. Businessman or host? Individual differences between entrepreneurs and small business owners in the hospitality industry. Serv. Ind. J. 2010, 30, 1513-1527. [CrossRef]

50. Smith, K.; Williams, D.; Yasin, N.; Pitchford, I. Enterprise skills and training needs of postgraduate research students. Educ. Train. 2014, 56, 745-763. [CrossRef]

51. Jelonek, M.; Urbaniec, M. Development of Sustainability Competencies for the Labour Market: An Exploratory Qualitative Study. Sustainability 2019, 11, 5716. [CrossRef]

52. Small, L.; Shacklock, K.; Marchant, T. Employability: A contemporary review for higher education stakeholders. J. Vocat. Educ. Train. 2018, 70, 148-166. [CrossRef]

53. Tuononen, T.; Parpala, A.; Lindblom-Ylänne, S. Graduates' evaluations of usefulness of university education, and early career success-a longitudinal study of the transition to working life. Assess. Eval. High. Educ. 2019, 44, 581-595. [CrossRef]

54. Hyttinen, K.; Ruoslahti, H.; Jokela, J. Model for Effective Integration between Research, Work Life and Higher Education in International Security Studies. In Proceedings of the 9th International Joint Conference on Knowledge Discovery, Knowledge Engineering and Knowledge Management, Funchal, Portugal, 1-3 November 2017; pp. 299-306. [CrossRef]

55. European Commission (EC). Europe 2020: A Strategy for Smart, Sustainable and Inclusive Growth, COM 2020; European Commission: Brussels, Belgium, 2010; Available online: https://ec.europa.eu/eu2020/pdf (accessed on 4 June 2019).

56. Ploum, L.; Blok, V.; Lans, T.; Omta, O. Toward a validated competence framework for sustainable entrepreneurship. Organ. Environ. 2017, 31, 113-132. [CrossRef]

57. Bunk, G.P. La transmisión de competencias en la formación y perfeccionamiento profesionales de la RFA. Revista Europea de Formación Profesional 1994, 1, 8-14. Available online: https://dialnet.unirioja.es/servlet/ articulo?codigo=131116 (accessed on 12 January 2020).

58. Boyatzis, R.E. The Competent Manager: A Model for Effective Performance; John Wiley and Sons: New York, NY, USA, 1982. [CrossRef]

59. Spencer, L.M.; Spencer, S.M. Competence at Work: Models for Superior Performance; John Wiley and Sons: New York, NY, USA, 1993.

60. Woodruffe, C. What is meant by a competency? Leadersh. Organ. Dev. J. 1993, 14, 29-36. [CrossRef]

61. Rodríguez, N.; Feliú, P. Manual Descriptivo y de Aplicación de la Prueba de Estilo Gerencial; PEGOL, PsicoConsult: Barcelona, Spain, 1996.

62. Mertens, L. La Gestión Por Competencia Laboral en la Empresa y la Formación Profesional; OEI: Madrid, Spain, 1996; Available online: https://www.oei.es/historico/oeivirt/fp/iberfop01.htm (accessed on 10 January 2020).

63. Fernández, J.M. Matriz de competencias del docente de educación básica. Rev. Iberoaméricana Educ. 2005, 36, 1-15. [CrossRef]

64. Martínez, A.; Sauleda, C. La Investigación Basada en el Diseño y el Diseño del Crédito Europeo, Investigar el Diseño Curricular: Redes de Docencia en el Espacio Europeo de Educación Superior; Universidad de Alicante: 
Alicante, Spain, 2005; pp. 7-22. Available online: http://rua.ua.es/dspace/handle/10045/20332 (accessed on 10 January 2020).

65. Collins, B. Perspectivas de Disseny al educatió per Competencias. In Proceedings of the Simposio Internacional, CIUDI, Universidad Politécnica de Cataluña, Barcelona, Spain, 2007.

66. Blanco Canto, M.; Bares López, L.; Hrynevych, O. The inclusion of transversal competences in the training programs for unemployed of Bahía De Cádiz. J. Tour. Anal. 2019. Available online: https://www.emerald. com/insight/content/doi/10.1108/JTA-04-2018-0013/full/html (accessed on 8 January 2020).

67. Tobón, S. La Formación Basada en Competencias en la Educación Superior: El Enfoque Complejo; Universidad Autónoma de Guadalajara: Zapopan, Mexico, 2008; Available online: http://eprints.uanl.mx/9784/1/Libro\% 20Formaci\%C3\%B3n\%20por\%20Competencias.pdf (accessed on 9 January 2020).

68. Álvarez, A.A. Competencias Profesionales: Análisis Conceptual y Aplicación Profesional; Seminario Permanente de Orientación Professional: Barcelona, Spain, 2003; Available online: http://www.edu.xunta.gal/centros/ cfrcoruna/system/files/Asumpta+Aneas.pdf (accessed on 9 January 2020).

69. Acebrón, A.M. Las Competencias Transversales en la Universidad Pompeu Fabra: La Visión de los Docentes y Estudiantes de Segundo Ciclo, Revista de Docencia UniversitariaRed U. Núm monográfico I. 2008. Available online: www.redu.um.es/Red_U/m (accessed on 9 January 2020).

70. Bozu, Z.; Canto, P.J. El profesorado universitario en la sociedad del conocimiento: Competencias profesionales docentes. Rev. Form. Innov. Educ. Univ. 2009, 2, 87-97. Available online: https://dialnet.unirioja.es/servlet/ articulo? codigo=3110877 (accessed on 9 January 2020).

71. Segovia-Pérez, M.; Laguna-Sánchez, P.; de la Fuente-Cabrero, C. Education for Sustainable Leadership: Fostering Women's Empowerment at the University Level. Sustainability 2019, 11, 5555. [CrossRef]

72. Phoenix report of Future Work Skills 2020. Institute for the Future for University of Phoenix Research Institute. 2011. Available online: http://www.iftf.org/uploads/media/SR-1382A_UPRI_future_work_skills_sm.pdf (accessed on 10 December 2019).

73. López, J.E.; Romero-Díaz de la Guardia, J.J.; Olmos-Gómez, M.C.; Chacón-Cuberos, R.; Olmedo Moreno, E.M. Enhancing Skills for Employment in the Workplace of the Future 2020 Using the Theory of Connectivity: Shared and Adaptive Personal Learning Environments in a Spanish Context. Sustainability 2019, 11, 4219. [CrossRef]

74. Ceresia, F.; Lo Sasso, E.M. A general framework for a standardized competence assessment procedure. Eur. Proc. Soc. Behav. Sci. 2017. [CrossRef]

75. Giroux, D.; Stibre, D. Validation of assessment of employability tool (OEA): A Delphi study. Can. J. Aging 2015, 34, 524-531. [CrossRef]

76. Boahin, P.; Eggink, J.; Hofman, A. Competency-based training in international perspective: Comparing the implementation processes towards the achievement of employability. J. Curric. Stud. 2014, 46, 839-858. [CrossRef]

77. Van der Klink, J.J.L.; Bultmann, U.; Burdorf, A.; Schaufeli, W.B.; Zijlstra, F.R.H.; Abma, F.I.; Brouwer, S.; van der Wilt, G.J. Sustainable employability-Definition, conceptualization, and implications: A perspective based on the capability approach. Scand. J. Work Environ. Health 2016, 42, 71-79. [CrossRef] [PubMed]

78. Pang, E.; Wong, M.; Leung, C.H.; Coombes, J. Competencies for fresh graduates' success at work: Perspectives of employers. Ind. High. Educ. 2019, 33, 55-65. [CrossRef]

79. Pop, C.; Khampirat, B. Self-assessment instrument to measure the competencies of Namibian graduates: Testing of validity and reliability. Stud. Educ. Eval. 2019, 60, 130-139. [CrossRef]

80. Vargas, R.; Inmaculada Sanchez-Queija, M.; Rothwell, A.; Parra, Á. Self-perceived employability in Spain. Educ. Train. 2018, 60, 226-237. [CrossRef]

81. Dastjerdi, M.M. The Relationship between the Job Search Efficacy and Job Search Beliefs with Employability. Int. J. Adv. Biotechnol. Res. 2016, 7, 811-814.

82. Baggen, Y.; Lans, T.; Biemans, H.J.; Kampen, J.; Mulder, M. Fostering Entrepreneurial Learning On-the-Job: Evidence from innovative small and medium-sized companies in Europe. Eur. J. Educ. 2016, 51, 193-209. [CrossRef]

83. Elfenbein, D.W.; Hamilton, B.H.; Zenger, T.R. The small firm effect and the entrepreneurial spawning of scientists and engineers. Manag. Sci. 2010, 56, 659-681. [CrossRef]

84. Collins, C.J.; Hanges, P.J.; Locke, E.A. The relationship of achievement motivation to entrepreneurial behavior: A meta-analysis. Hum. Perform. 2004, 17, 95-117. [CrossRef] 
85. Oehler, A.; Höfer, A.; Schalkowski, H. Entrepreneurial education and knowledge: Empirical evidence on a sample of German undergraduate students. J. Technol. Transf. 2015, 40, 536-557. [CrossRef]

86. European Commission. The European Higher Education Area in 2018; European Commission, 2018; Available online: https://eacea.ec.europa.eu/national-policies/eurydice/sites/eurydice/files/bologna_internet_0.pdf (accessed on 4 November 2019).

(C) 2020 by the authors. Licensee MDPI, Basel, Switzerland. This article is an open access article distributed under the terms and conditions of the Creative Commons Attribution (CC BY) license (http://creativecommons.org/licenses/by/4.0/). 